\title{
Morphometry of Cornops aquaticum (Orthoptera: Acrididae: Leptysminae) in the Pantanal of Mato Grosso, Brazil
}

\author{
Silva, FRJ. ${ }^{a *}$, Battirola, LD. ${ }^{b}$, Lhano, MG. ${ }^{c}$, Sousa, WO. ${ }^{d}$ and Marques, MI. ${ }^{a}$ \\ aPrograma de Pós-Graduação em Ecologia e Conservação da Biodiversidade, Universidade Federal de Mato Grosso - UFMT, \\ Av. Fernando Corrêa da Costa, s/n, Coxipó, CEP 78060-900, Cuiabá, MT, Brazil \\ 'Instituto de Ciências Naturais, Humanas e Sociais, Universidade Federal de Mato Grosso - UFMT, \\ Campus Universitário de Sinop, Av. Alexandre Ferronato, 1200, Setor Industrial, CEP 78557-267, Sinop, MT, Brazil \\ ${ }^{\mathrm{c}}$ Centro de Ciências Agrárias, Ambientais e Biológicas - CCAAB, Universidade Federal do Recôncavo da Bahia - UFRB, \\ Rua Rui Barbosa, 710, Centro, CEP 44380-000, Cruz das Almas, BA, Brazil \\ dinstituto de Ciências Exatas e da Terra, Universidade Federal de Mato Grosso - UFMT, Campus Universitário do \\ Araguaia, Av. Valdon Varjão, 6390, CEP 78600-000, Barra do Garças, MT, Brazil \\ *e-mail: fateca@gmail.com; marinez@ufmt.br
}

Received: March 11, 2013 - Accepted: May 9, 2013 - Distributed: August 31, 2014

(With 9 figures)

\begin{abstract}
Insects show morphometric variations associated with the environment that may be the result of phenotypic response or genetic inheritance, or both. Thereby, studies that emphasise the variability in body size are very useful for understanding the dynamics and the stability of ecological systems. Cornops aquaticum (Bruner, 1906) (Acrididae) is a semi-aquatic grasshopper, distributed from the southeast of Mexico to the south of Buenos Aires Province, Argentina, and is intimately associated with the aquatic macrophytes Eichhornia spp. and Pontederia spp. In its wide habitat distribution, C. aquaticum shows variations in its life cycle and morphometric differences that were observed suggesting geographic and host plant influence. Considering these findings, this study aimed to find out the morphometric characteristics of this species at the Pantanal of Poconé - MT, using the protocol of the project "HICWA - Host-Insect Coevolution on Waterhyacinth", as well as to assess possible differences in each stage of development between the sexes and among seasonal periods (flood, high water, low water and dry). During 12 months a total of 600 individuals were collected in monthly collections of 50 grasshoppers, and of this total, 261 were adults and 339 nymphs. The following measurements were taken: total length (A); body length (B); wing length (I) and measurement of the hind femur (H). The results showed that both male and female have different measurements but not correlated with seasonal periods. The average obtained for each character and the seasonality showed the highest values during the flood period. In nymphs, the measurement of the posterior femur presented the lower variation between individuals and characters.
\end{abstract}

Keywords: body size, development, grasshopper, sexual dimorphism, Pantanal.

\section{Morfometria de Cornops aquaticum (Orthoptera: Acrididae: Leptysminae) no Pantanal de Mato Grosso, Brasil}

\begin{abstract}
Resumo
Insetos apresentam variações morfométricas associadas ao ambiente que podem ser resultado tanto de respostas fenotípicas, quanto da herança genética, ou de ambos. Assim, estudos que enfatizam a variabilidade no tamanho do corpo do inseto são de grande utilidade para o entendimento da dinâmica e da estabilidade dos sistemas ecológicos. Cornops aquaticum (Bruner, 1906) (Acrididae) é um gafanhoto semi-aquático, distribuído desde o sudeste do México até o sul da província de Buenos Aires, Argentina, demonstrando íntima associação com macrófitas aquáticas dos gêneros Eichhornia e Pontederia. Em sua ampla distribuição de habitats, C. aquaticum apresenta variações em seu ciclo biológico e diferenças morfométricas que sugerem uma influência tanto geográfica, quanto da planta hospedeira. Diante disto, esse estudo objetivou conhecer as características morfométricas dessa espécie no Pantanal de Poconé (MT), empregando o protocolo do projeto "HICWA - Host-Insect Coevolution on Waterhyacinth", bem como avaliar possíveis diferenças em cada estádio de desenvolvimento entre os sexos e entre os períodos sazonais dessa região (enchente, cheia, vazante e seca). Durante 12 meses foram coletados, mensalmente, 50 gafanhotos, totalizando 600 indivíduos, sendo 261 adultos e 339 ninfas, nos quais foram tomadas as medidas do comprimento total (A); comprimento do corpo (B); comprimento da asa (I) e medida do fêmur posterior $(\mathrm{H})$. Os resultados indicam indivíduos adultos, tanto
\end{abstract}


machos quanto fêmeas, de tamanho variado em todos os períodos sazonais, entretanto, essas variações não estão correlacionadas à sazonalidade. As médias obtidas para cada caracter entre os períodos sazonais demonstraram que houve diferenciação entre as medidas, revelando os maiores valores médios durante a enchente. Em ninfas, a menor variação entre os indivíduos em relação aos outros caracteres avaliados foi encontrada na medida do fêmur posterior.

Palavras-chave: tamanho corpóreo, desenvolvimento, gafanhoto, dimorfismo sexual, Pantanal.

\section{Introduction}

Insects show morphometric variations associated with the environment which may be result of either phenotypical responses or genetic inheritance, or both. Begon et al. (2006) reported that the individuals that composed a species population are not identical and may vary, sometimes very slightly, in size, development rate and/or in response to temperature. Studies point out that the variation in body size is a property of natural populations and has important ramifications for the understanding of the dynamics and stability of ecological systems (Filin and Ovadia, 2007).

Assessing the morphometric characteristics of insects has been very useful in population studies, in terms of communities, and is used for the identification of nymph stages, features of sexual dimorphism (Zolessi, 1956; Turk and Barrera, 1976; Cepeda-Pizarro et al., 2003; Domenico, 2005; Cherril, 2005; Franceschini et al., 2005; Ferreira et al., 2006; Seffrin et al., 2006), life history and evolution with host plants (Klingenberg and Spence, 1997; Ahnesjö and Forsman, 2003; Adis et al., 2008), as well as ecological studies of populations and communities (Dirsh, 1953; Roonwal, 1981; Filin and Ovadia 2007; Pires et al., 2008).

Cornops aquaticum (Bruner, 1906) (Orthoptera: Acrididae: Leptysminae) is a semi-aquatic grasshopper and is found from the south-east of Mexico down to the south of Buenos Aires Province, Argentina (Adis et al., 2007). Its biological life cycle is developed based on the Pontederiaceae macrophytes Eichhornia crassipess (Mart.) Solms, E. azurea (Sw.) Kunth, Pontederia cordata L. and P. lanceolata Nutt. (Zolessi, 1956; Guido and Perkins, 1975; Adis and Victoria, 2001; Ferreira and VasconcellosNeto, 2001; Lhano et al., 2005; Adis et al., 2007). These native South American plants introduced into different tropical and sub-tropical areas around the world and in some cases have become damaging mainly due to human action (Oberholzer and Hill, 2001).

Due to the grasshopper's affinity to its plant host, its use as a biological control agent is being studied and, to this end, a population of C. aquaticum was established in Pretoria, South Africa, using individuals from a variety of locations in South America so that research can be done on its host plant specificity, feeding preferences, capacity to adapt, genetic studies and phenotypical plasticity. This knowledge is required so that use of this insect is safe and meets objectives (Oberholzer and Hill, 2001).

With widely distributed habitats in locations with differing climatic factors, studies show that $C$. aquaticum has variable biological life cycles with differing numbers of instars and alterations to its voltinism (Adis and Junk, 2003; Adis et al., 2004; Brede et al., 2007).
When comparing the population in quarantine in the Pretoria laboratory, studying South American populations, morphometric differences are found which suggest the influence of both geographical location and host plant on the body size of these insects (Adis et al., 2008). These differences between the populations can be explained by the influence of environmental variations on the selection and adaptation behaviour of these organisms producing a phenotypical plasticity (West-Eberhard, 1989) which is one of the factors that needs to be analysed when using a species for biological control.

Faced with the need to better understand the biology and ecology of this insect, the "HICWA - Host-Insect Coevolution on Waterhyacinth project was set up involving ten countries (Argentina, Brazil, Colombia, France, Germany, South Africa, Nicaragua, Trinidad and Tobago, the United Kingdom and Uruguay), in order to research the coevolution of $C$. aquaticum with its host plants (Adis et al., 2008). This study is part of the HICWA Project and aims to describe the morphometric aspects of C. aquaticum in the Pantanal of Mato Grosso, Brazil, a non-isolated population in an area predominated occupied by E. azurea in natural conditions, for subsequent comparison with other locations involved in this project.

\section{Materials and Methods}

\subsection{Study area}

Sample collections were taken from the Piuval bay located in the Fazenda Ipiranga, Km 10 along the Transpantaneira Road (16 24'00 S and 56 37'00 W) in the Poconé of Pantanal in Mato Grosso state, in the period from March 2006 to February 2007. The Piuval bay is originated by the flooding of the Bento Gomes River near to Poconé County, Mato Grosso State, which is a seasonally flooded area during the rainy season that possibility the formation of bays and lakes which remain until the middle of July (Fortney et al., 2004).

The predominant macrophyte in the bay during the whole collection period was E. azurea in association with other species that the occurrence alternated throughout the year. During flood and low water seasons, plants of the Nymphaeaceae family were found over the central part of the bay. Other plants presented during the collection period were Salvinia spp. (Salviniaceae), E. crassipes, Pontederia subovata (Seub.) Lowden, P. parviflora Alexander (Pontederiaceae), Ludwigia spp. (Onagraceae), Cyperus giganteus Vahl (Cyperaceae) and Pistia stratiotes L. (Araceae). 
The Pantanal of Mato Grosso is a floodplain where the flood pulse is relatively predictable and corresponds to an annual hydrological cycle, separated into two distinct phases: terrestrial and aquatic, divided over the year into four periods: flood (rainy terrestrial phase), high water (aquatic phase, inundation), low water (aquatic phase, water level falling), dry season (terrestrial phase without rain) (Junk et al., 2006).

\subsection{Methodology}

In accordance with the methodology defined by the HICWA Project, monthly collections were made of 50 grasshoppers using an insect net $(70 \mathrm{~cm}$ in diameter and 1 metre long) on a slow-moving motor boat, independent of the time. The animals collected were placed in a plastic bag, with some E. azurea leaves inside, and transported live in polystyrene boxes to the Arthropod Ecology and Taxonomy Laboratory (LETA) of the Biosciences Institute of the Federal University of Mato Grosso (UFMT). Here they were frozen in an ordinary freezer until dead and then separated into adults and nymphs and their sex was established. The nymphs were separated according to their state of development. To determine the nymph stages, the hind femur measurement was used as suggested by Franceschini et al., (2005), and to establish the sex of the nymphs, illustrations of the male and female genitalia by Lhano (2002) were used.

The morphological features were measured in accordance with Carbonell's (2002) criteria and categorised as follows: A - total length, from the meridian to the end of the wing pads (nymphs) and of the tegmen (adults); B - body length, from the meridian to the end of the abdomen; I - wing length (adults only); and H- size of hind femur (Figures 1.1 and 1.2). The measurements were carried out using a stereoscopic, binocular microscope and millimetre graded paper. Each morphometric variable was described in terms of the sample mean (X), standard deviation (SD), highest and lowest values found $(\mathrm{Rg})$ and the variation coefficient (VC) for each of the categories both in nymphs and adults using InfoStat (2002) software, observing the possible differences in each developmental stage, between the sexes and between the different seasonal periods found in this region.

To assess the differences between the seasonal periods, the measurements were analysed within each of the categories $(\mathrm{A}, \mathrm{B}, \mathrm{I}$ and $\mathrm{H})$ using variance analysis (ANOVA - One way) $(\alpha=0.05)$ as a reference and testing variance homogeneity and the mean equalities from the Levene Test and the " $\mathrm{F}$ " Test. To complement this study a multivariate, discriminating analysis (MANOVA - CVA, PAST v.1.81) was employed, which allows for the visualisation of the morphological similarities between the individuals in the different seasonal periods by means of the projection of individual values for each period placed on the canonic axis of a bi-dimensional graph inputting the significance values of the differences between the mean values for each feature (Hammer and Harper, 2008).
(1)

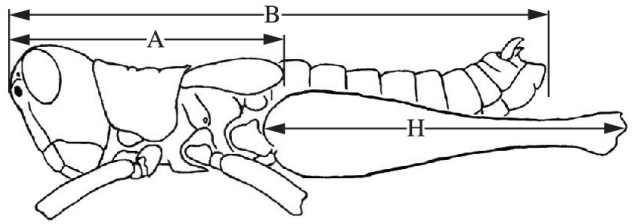

(2)

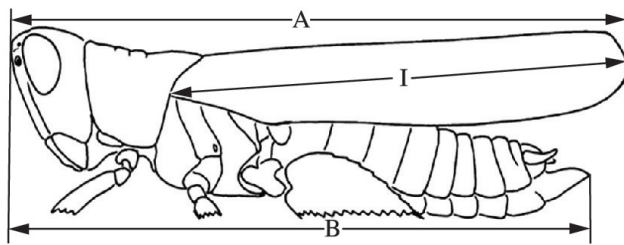

Figures 1. Morphometric measurements in grasshoppers, nymphs (1) and adults (2), in accordance with Carbonell (2002). Nymphs (A - total length, from the meridian to the end of the wing pads; $\mathrm{B}$ - body length, from the meridian to the end of the abdomen and $\mathrm{H}$ - size of hind femur) and adults ( $\mathrm{A}$ - total length, from the meridian to the end of the tegmen; B - body length, from the meridian to the end of the abdomen and I - wing length).

\section{Results}

Over twelve months, 600 individuals were collected and measured of which 261 were adults and 339 nymphs. The nymphs were classified into each developmental stage as described in Table 1 whereby the size of the hind femur (H) showed the lowest variation coefficients in relation to the other morphometric features.

The measurement with the greatest variation within each stage was the distance between the meridian and the end of the tegmen (A) which, in the fourth stage, has a coefficient of $21.03 \%$ for males and $16.58 \%$ for females. Although this measurement includes sclerite parts of the body, this result is influenced by wing growth which may not be uniform amongst the nymphs.

Cornops aquaticum possesses sexual dimorphism with adult males being smaller than the females. This difference probably occurs in the last developmental instars since in the sixth stage measurement (B), the body size (from the meridian to the end of the abdomen) presented the highest values of $24 \mathrm{~mm}$ for males and $27 \mathrm{~mm}$ for females (Table 1), indicating the existence of distinct individuals although the mean did not show significant differences.

In the assessment of the nymph morphometry between the seasonal periods (low water, dry, flood and high water season), only the variation of the " $\mathrm{H}$ " measurement (femur size) was significant in stage II (Table 2) with the lowest values recorded being for females during the inundation period, influencing the variance analysis with different results between the sexes, $\mathrm{F}=1.70, p=0.190$ for males and $\mathrm{F}=5.48, p=0.002$ for females

The measurements of adults showed little variation within the months. During the whole collection period the only records of significant variation coefficient occurred for features " $\mathrm{A}$ " and "I" in the month of March 2006 with values 
Table 1. Morphometric data obtained from each nymph stage of C. aquaticum collected from the Piuval bay, in the Pantanal of Poconé, MT.

\begin{tabular}{|c|c|c|c|c|c|c|c|}
\hline \multirow{2}{*}{ Stage } & & \multicolumn{3}{|c|}{ Males } & \multicolumn{3}{|c|}{ Females } \\
\hline & & $\mathbf{A}^{*}$ & B & $\mathbf{H}$ & $\mathbf{A}$ & B & H \\
\hline \multirow[t]{5}{*}{ I } & $\mathbf{X}$ & 3.24 & 6.93 & 3.62 & 3.29 & 7.1 & 3.71 \\
\hline & SD & 0.37 & 0.87 & 0.31 & 0.4 & 0.79 & 0.34 \\
\hline & Rg & $2.5-4.0$ & $5.0-9.0$ & $3.0-4.0$ & $2.5-4.5$ & $5.5-9.0$ & $3.0-4.0$ \\
\hline & $\mathrm{VC}$ & 11.57 & 12.56 & 8.63 & 12.37 & 10.98 & 9.06 \\
\hline & $\mathbf{n}$ & 21 & & & 31 & & \\
\hline \multirow[t]{5}{*}{ II } & $\mathbf{X}$ & 3.96 & 9.07 & 4.93 & 4.06 & 9.31 & 4.86 \\
\hline & SD & 0.5 & 1.12 & 0.17 & 0.42 & 0.92 & 0.31 \\
\hline & Rg & $3.0-5.0$ & $6.0-11.0$ & $4.5-5.0$ & $3.0-5.0$ & $7.5-11.0$ & $4.0-5.5$ \\
\hline & VC & 12.59 & 12.37 & 3.49 & 10.26 & 9.93 & 6.45 \\
\hline & $\mathbf{n}$ & 23 & & & 45 & & \\
\hline \multirow[t]{5}{*}{ III } & $\mathbf{X}$ & 5.09 & 11.88 & 6.45 & 5.06 & 11.68 & 6.5 \\
\hline & SD & 0.48 & 1.2 & 0.45 & 0.72 & 1.21 & 0.52 \\
\hline & Rg & $4.0-6.5$ & $10.0-15.0$ & $6.0-7.0$ & $3.0-7.0$ & $10.0-14.0$ & $5.0-7.5$ \\
\hline & $\mathrm{VC}$ & 9.37 & 10.28 & 6.93 & 14.18 & 10.38 & 8.07 \\
\hline & $\mathbf{n}$ & 38 & & & 41 & & \\
\hline \multirow[t]{5}{*}{ IV } & $\mathbf{X}$ & 8.16 & 15.51 & 8.66 & 7.85 & 16.31 & 8.97 \\
\hline & SD & 1.72 & 1.56 & 0.82 & 1.30 & 1.56 & 0.83 \\
\hline & Rg & $6.0-12.0$ & $13.0-20.0$ & $8.0-10.0$ & $5.5-11.5$ & $12.5-19.0$ & $8.0-10.0$ \\
\hline & VC & 21.03 & 10.06 & 9.43 & 16.58 & 9.56 & 9.19 \\
\hline & $\mathbf{n}$ & 37 & & & 47 & & \\
\hline \multirow[t]{5}{*}{$\mathbf{V}$} & $\mathbf{X}$ & 11.18 & 18.48 & 10.25 & 11.50 & 20.31 & 10.98 \\
\hline & SD & 1.40 & 1.59 & 0.92 & 1.91 & 1.52 & 0.66 \\
\hline & Rg & $7.5-13.0$ & $14.0-21.0$ & $8.0-11.50$ & $9.0-14.0$ & $17.0-23.0$ & $10.0-12.0$ \\
\hline & $\mathrm{VC}$ & 12.51 & 8.58 & 9.02 & 16.61 & 7.49 & 6.02 \\
\hline & $\mathbf{n}$ & 20 & & & 21 & & \\
\hline \multirow[t]{5}{*}{ VI } & $\mathbf{X}$ & 13.63 & 21.75 & 12.25 & 14.09 & 21.45 & 12.27 \\
\hline & SD & 1.1 & 2.1 & 0.5 & 1.6 & 2.2 & 0.5 \\
\hline & Rg & $12.5-15.0$ & $19.0-24.0$ & $12.0-13.0$ & $13.0-18.5$ & $18.5-27.0$ & $12.0-13.0$ \\
\hline & VC & 8.14 & 9.48 & 4.08 & 11.31 & 10.34 & 3.81 \\
\hline & $\mathbf{n}$ & 4 & & & 11 & & \\
\hline
\end{tabular}

*A - total length, from the meridian to the end of the tegmen; B - body length, from the meridian to the end of the abdomen and $\mathrm{H}$ - size of hind femur (Figure 1.1); X - sample mean, SD - Standard Deviation, Rg - maximum and minimum values found and $\mathrm{VC}$ - the variation coefficient.

Table 2. Variance analysis (ANOVA) for the differences in the development stages and in the seasonal periods in C. aquaticum in the Piuval bay, Pantanal of Poconé, MT.

\begin{tabular}{lcccccccccccc}
\hline Stages & & I & \multicolumn{2}{c}{ II } & \multicolumn{2}{c}{ III } & \multicolumn{1}{c}{ IV } & \multicolumn{2}{c}{ V } & \multicolumn{2}{c}{ VI } \\
\hline & $\mathbf{F}$ & $\boldsymbol{p}$ & $\mathbf{F}$ & $\boldsymbol{p}$ & $\mathbf{F}$ & $\boldsymbol{P}$ & $\mathbf{F}$ & $\boldsymbol{p}$ & $\mathbf{F}$ & $\boldsymbol{p}$ & $\mathbf{F}$ & $\boldsymbol{p}$ \\
\hline $\mathbf{A}^{*}$ & 0.87 & 0.459 & 0.36 & 0.778 & 5.03 & $\mathbf{0 . 0 0 3}$ & 1.51 & 0.217 & 2.65 & 0.062 & 0.48 & 0.697 \\
$\mathbf{B}$ & 0.71 & 0.547 & 0.47 & 0.690 & 2.72 & 0.050 & 0.45 & 0.717 & 2.35 & 0.088 & 2.25 & 0.139 \\
$\mathbf{H}$ & 0.89 & 0.449 & 7.41 & $<\mathbf{0 . 0 0 1}$ & 1.12 & 0.347 & 1.41 & 0.244 & 1.81 & 0.162 & 1.20 & 0.354 \\
\hline
\end{tabular}

*A - total length, from the meridian to the end of the tegmen; B - body length, from the meridian to the end of the abdomen and $\mathrm{H}-$ size of hind femur.

of $20.69 \%$ and $22.77 \%$, respectively (Table 3 ). The adult individuals of this population possess sexual dimorphism whereby all the measurements assessed showed significant differences between males and females with distinct sizes between the sexes as seen in the multivariate analysis (Wilk's lambda $=0.20$, Pillai trace $=0.79, \mathrm{~F}=251.4$, $p<0.001$ ), evidence that the males are smaller than the females (Figure 2).

The results of the multivariate analyses for the differences between the seasonal periods are significant in males and females for measurements "A", "B", "I" and "H" (Table 4). The measurements obtained for each feature between 
Table 3. Morphometric data obtained from adult C. aquaticum collected from the Piuval bay, in the Pantanal of Poconé, MT.

\begin{tabular}{|c|c|c|c|c|c|c|c|c|c|}
\hline \multirow{2}{*}{ Month } & & \multicolumn{4}{|c|}{ Males } & \multicolumn{4}{|c|}{ Females } \\
\hline & & $\mathbf{A}^{*}$ & B & I & $\mathbf{H}$ & $\mathbf{A}$ & B & I & $\mathbf{H}$ \\
\hline \multirow[t]{5}{*}{ March } & $X$ & 25.3 & 20.45 & 18.7 & 11.7 & 28.83 & 25.0 & 21.67 & 14.5 \\
\hline & SD & 1.87 & 1.83 & 1.57 & 0.48 & 5.97 & 2.65 & 4.93 & 1.32 \\
\hline & $\mathrm{Rg}$ & $21.5-28.0$ & $16.0-23.0$ & $15.5-21.0$ & $11.0-12.0$ & $22.0-33.0$ & $22.0-27.0$ & $16.0-25.0$ & $13.0-15.5$ \\
\hline & $\mathrm{VC}$ & 7.41 & 8.96 & 8.38 & 4.13 & 20.69 & 10.58 & 22.77 & 9.12 \\
\hline & $\mathrm{X}$ & 24.79 & 19.71 & 18.86 & 11.93 & 27.1 & 23.7 & 19.7 & 14.4 \\
\hline \multirow[t]{4}{*}{ April } & SD & 1.47 & 0.76 & 1.21 & 0.45 & 3.65 & 2.49 & 2.89 & 0.65 \\
\hline & $\mathrm{Rg}$ & $22.5-26.0$ & $19.0-21.0$ & $17.0-20.0$ & $11.0-12.5$ & $22.0-30.0$ & $21.0-27.5$ & $15.5-22.5$ & $13.5-15.0$ \\
\hline & $\mathrm{VC}$ & 5.92 & 3.83 & 6.44 & 3.77 & 13.46 & 10.51 & 14.65 & 4.53 \\
\hline & $\mathrm{X}$ & 25.93 & 20.0 & 19.43 & 11.57 & 32.2 & 25.7 & 23.4 & 15.6 \\
\hline \multirow[t]{4}{*}{ May } & SD & 1.54 & 0.82 & 1.27 & 0.98 & 1.3 & 1.15 & 1.19 & 0.89 \\
\hline & $\mathrm{Rg}$ & $24.0-28.0$ & $19.0-21.0$ & $18.0-21.0$ & $10.0-13.0$ & $31.0-34.0$ & $24.0-26.5$ & $22.0-25.0$ & $14.0-16.0$ \\
\hline & $\mathrm{VC}$ & 5.94 & 4.08 & 6.55 & 8.43 & 4.05 & 4.48 & 5.1 & 5.73 \\
\hline & $\mathrm{X}$ & 25.4 & 19.4 & 18.9 & 11.6 & 32.5 & 25.8 & 25.0 & 14.0 \\
\hline \multirow[t]{4}{*}{ June } & $\mathrm{SD}$ & 1.24 & 0.76 & 1.05 & 0.5 & 1.6 & 1.28 & 2 & 0.93 \\
\hline & $\mathrm{Rg}$ & $24.0-28.0$ & $18.0-21.0$ & $17.0-21.0$ & $11.0-12.0$ & $29.0-34.0$ & $23.0-27.0$ & $22.0-29.0$ & $13.0-15.0$ \\
\hline & $\mathrm{VC}$ & 4.9 & 3.89 & 5.55 & 4.27 & 4.93 & 4.98 & 0 & 6.61 \\
\hline & $\mathrm{X}$ & 25.75 & 20.63 & 19.71 & 11.08 & 32.25 & 26.63 & 23.81 & 13.88 \\
\hline \multirow[t]{4}{*}{ July } & SD & 1.86 & 1.3 & 2.12 & 0.79 & 1.75 & 0.92 & 1.6 & 0.35 \\
\hline & $\mathrm{Rg}$ & $23.0-28.0$ & $18.5-23$ & $17.0-24.5$ & $9.0-12.0$ & $29.0-35.0$ & $25.0-28.0$ & $22.0-27.0$ & $13.0-14.0$ \\
\hline & $\mathrm{VC}$ & 7.24 & 6.3 & 10.73 & 7.15 & 1.75 & 0.92 & 1.6 & 0.35 \\
\hline & $\mathrm{X}$ & 27 & 21.09 & 20.0 & 11.73 & 32.5 & 26.82 & 24.68 & 14.55 \\
\hline \multirow[t]{4}{*}{ August } & SD & 1.48 & 1.04 & 2.31 & 0.47 & 1.79 & 1.94 & 1.35 & 0.69 \\
\hline & $\mathrm{Rg}$ & $24.0-29.0$ & $19.0-22.0$ & $14.0-22.0$ & $11.0-12.0$ & $29.0-34.5$ & $24 .-29.0$ & $22 .-27.0$ & $13.0-15.0$ \\
\hline & $\mathrm{VC}$ & 5.49 & 4.95 & 11.57 & 3.98 & 5.5 & 7.23 & 5.46 & 4.73 \\
\hline & $\mathrm{X}$ & 26.88 & 21.63 & 20.29 & 12.17 & 32.3 & 28.2 & 24.67 & 14.47 \\
\hline \multirow[t]{4}{*}{ September } & SD & 1 & 0.92 & 0.95 & 0.48 & 1.68 & 1.74 & 1.53 & 0.64 \\
\hline & $\mathrm{Rg}$ & 24.-29 & $20.0-24.0$ & $18.0-23.0$ & $11.0-13.0$ & $29.0-34.0$ & $25.0-31.0$ & $21.0-26.0$ & $13.0-15.0$ \\
\hline & $\mathrm{VC}$ & 3.73 & 4.27 & 4.7 & 3.96 & 5.19 & 6.17 & 6.21 & 4.42 \\
\hline & $\mathrm{X}$ & 27.42 & 21.16 & 20.95 & 12.16 & 33.19 & 27.06 & 25.14 & 14.72 \\
\hline \multirow[t]{4}{*}{ October } & SD & 0.93 & 0.96 & 0.96 & 0.5 & 2.79 & 1.39 & 1.81 & 0.83 \\
\hline & $\mathrm{Rg}$ & $25.5-29.0$ & $19.0-23.0$ & $19.0-23.0$ & $11.0-13.0$ & $27.0-40.0$ & $25.0-30.0$ & $21.0-30.0$ & $14.0-17.0$ \\
\hline & $\mathrm{VC}$ & 2.38 & 5.19 & 2.9 & 4.08 & 10.57 & 11.93 & 13.46 & 12.82 \\
\hline & $\mathrm{X}$ & 27.23 & 20.32 & 20.82 & 12.36 & 32.75 & 26.33 & 23.33 & 15.33 \\
\hline \multirow[t]{4}{*}{ November } & SD & 0.65 & 1.06 & 0.6 & 0.5 & 3.46 & 3.14 & 3.14 & 1.97 \\
\hline & $\mathrm{Rg}$ & $26 .-28$ & $19.0-23.0$ & $20.0-22.0$ & $12.0-13.0$ & $26.0-36.0$ & $20.0-28.0$ & $19.0-27.0$ & $12.0-18.0$ \\
\hline & $\mathrm{VC}$ & 2.38 & 5.19 & 2.9 & 4.08 & 3.46 & 3.14 & 3.17 & 1.97 \\
\hline & $\mathrm{X}$ & 26.54 & 21.54 & 19.96 & 12.15 & 33.65 & 28.3 & 25 & 15.6 \\
\hline \multirow[t]{4}{*}{ December } & SD & 1.33 & 1.33 & 1.2 & 0.52 & 0.82 & 1.77 & 1.05 & 0.84 \\
\hline & $\mathrm{Rg}$ & $24.0-29.0$ & $20.0-24.0$ & $18.0-22.0$ & $11.0-13.0$ & $32.0-35.0$ & $25.0-30.0$ & $23.0-26.0$ & $15.0-17.0$ \\
\hline & $\mathrm{VC}$ & 5.01 & 6.18 & 6 & 4.24 & 0.82 & 1.77 & 1.05 & 0.84 \\
\hline & $\mathrm{X}$ & 25.42 & 21.17 & 19.17 & 11.92 & 29.6 & 26 & 21.6 & 13.6 \\
\hline \multirow[t]{4}{*}{ January } & SD & 1.52 & 1.03 & 1.47 & 0.42 & 1.14 & 1.22 & 1.14 & 0.55 \\
\hline & $\mathrm{Rg}$ & $23.5-28.0$ & $20 .-23$ & $17.0-22.0$ & $11.5-13.0$ & $28.0-31.0$ & $24.0-27.0$ & $20.0-23.0$ & $13.0-14.0$ \\
\hline & $\mathrm{VC}$ & 5.98 & 4.87 & 7.65 & 3.5 & 3.85 & 4.71 & 5.28 & 4.03 \\
\hline & $\mathrm{X}$ & 26.74 & 22 & 20.06 & 11.94 & 31.7 & 26.9 & 23.7 & 14.2 \\
\hline \multirow[t]{3}{*}{ February } & SD & 1.09 & 1.06 & 1.33 & 0.56 & 2.11 & 2.13 & 1.49 & 0.79 \\
\hline & $\mathrm{Rg}$ & $25.0-29.0$ & $20.0-24.0$ & $18.0-22.0$ & $11.0-13.0$ & $29.0-36.0$ & $24.0-31.0$ & $22.0-27.0$ & $13.0-16.0$ \\
\hline & $\mathrm{VC}$ & 4.08 & 4.82 & 6.65 & 4.65 & 2.11 & 2.13 & 1.49 & 0.79 \\
\hline
\end{tabular}

*A - total length, from the meridian to the end of the tegmen; B - body length, from the meridian to the end of the abdomen, $\mathrm{I}$ - wing length (Figure 1.2) and H- size of hind femur (Figure 1.1); X - sample mean, SD - Standard Deviation, Rg maximum and minimum values found and $\mathrm{VC}$ - the variation coefficient. 
the seasonal periods showed that there were differences between the measurements revealing the greatest mean values during the flood period, indicating that the largest individuals were found in this period (Figures 3).

The multivariate analyses showed significant differences between the size of the males (Wilk's lambda $=0,58$, Pillai trace $=0,48, F=7,32, p<0.001$ ), and females (Wilk's lambda $=0,58$, Pillai trace $=0,47, \mathrm{~F}=4,61, p<0.001$ ), however, these results are not sufficient to be able to state that there are individuals with multi-pattern sizes in any of the seasonal periods (Figures 4). Thus, it can be inferred

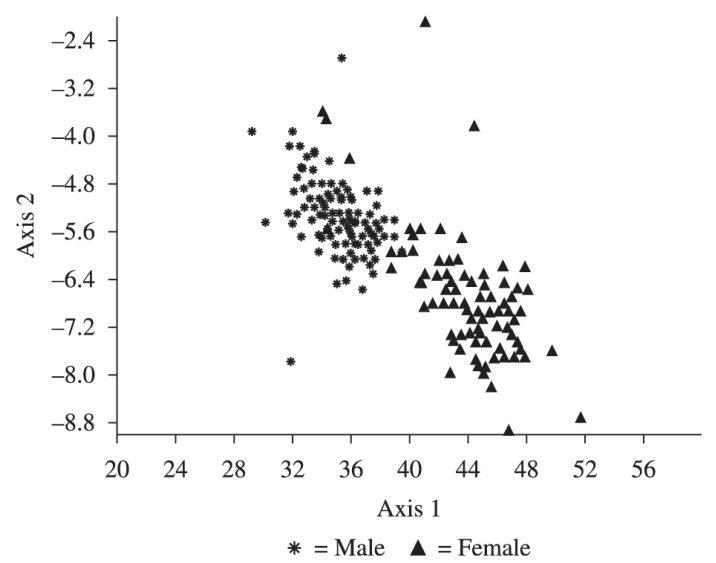

Figure 2. Canonic variables calculated in multivariate analysis (MANOVA) for individual adult C. aquaticum, males and females showing sexual dimorphism in the Piuval bay, Pantanal of Poconé, MT.
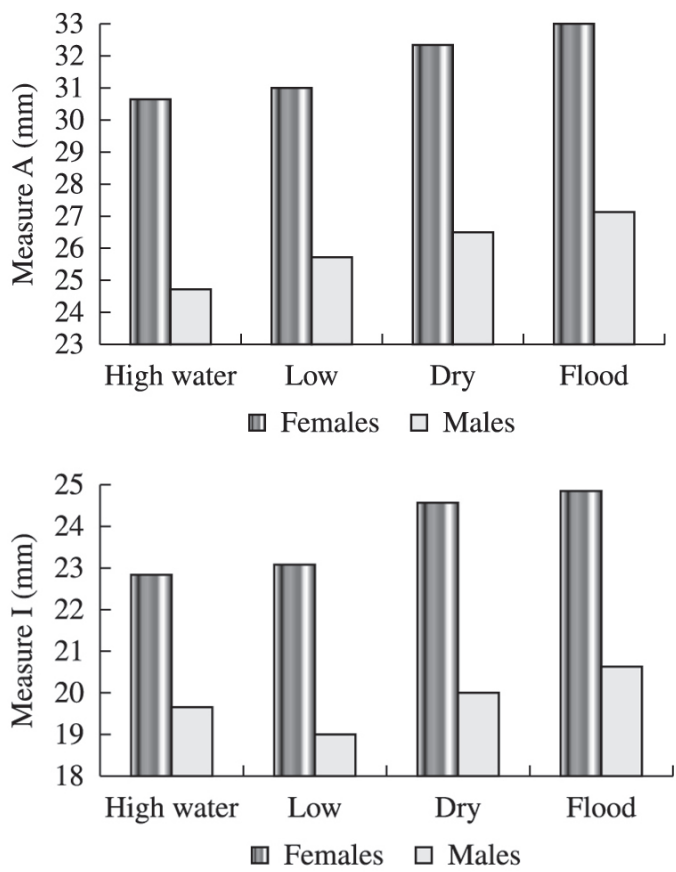

that this population presents individuals of various sizes in all periods, both in males and females.

\section{Discussion}

The results found here indicate that in nymphs the hind femur measurement $(\mathrm{H})$, has the lowest variation in relation to the other assessed features and that, in general, there was little variation in the measurements of the features both within instars and between the seasonal periods. In nymphs the features found had similar size patterns to the populations assessed in Uruguay and Argentina.

The low variation observed in the size of the hind femur, in nymphs, confirms the efficiency of the use of this morphological feature as being the best way to differentiate between the nymph stages in C. aquaticum as already suggested by Franceschini et al., (2005). This

Table 4. Variance analysis (ANOVA) for the differences in measurements A, B, I and $\mathrm{H}$, between the seasonal periods in C. aquaticum males and females, in the Piuval bay, Pantanal of Poconé, MT.

\begin{tabular}{crccr}
\hline & \multicolumn{2}{c}{ Males } & \multicolumn{2}{c}{ Females } \\
\hline & \multicolumn{1}{c}{ F } & $p$ & \multicolumn{1}{c}{ F } & \multicolumn{1}{c}{$p$} \\
\hline $\mathbf{A}^{*}$ & 6.88 & $<0.001$ & 5.87 & 0.001 \\
$\mathbf{B}$ & 14.38 & $<0.001$ & 6.68 & $<0.001$ \\
$\mathbf{I}$ & 10.02 & $<0.001$ & 5.17 & 0.002 \\
$\mathbf{H}$ & 5.51 & 0.001 & 5.7 & 0.001 \\
\hline
\end{tabular}

*A - total length, from the meridian to the end of the tegmen; $\mathrm{B}$ - body length, from the meridian to the end of the abdomen, $\mathrm{I}$ - wing length (Figure 1.2) and $\mathrm{H}$ - size of hind femur.
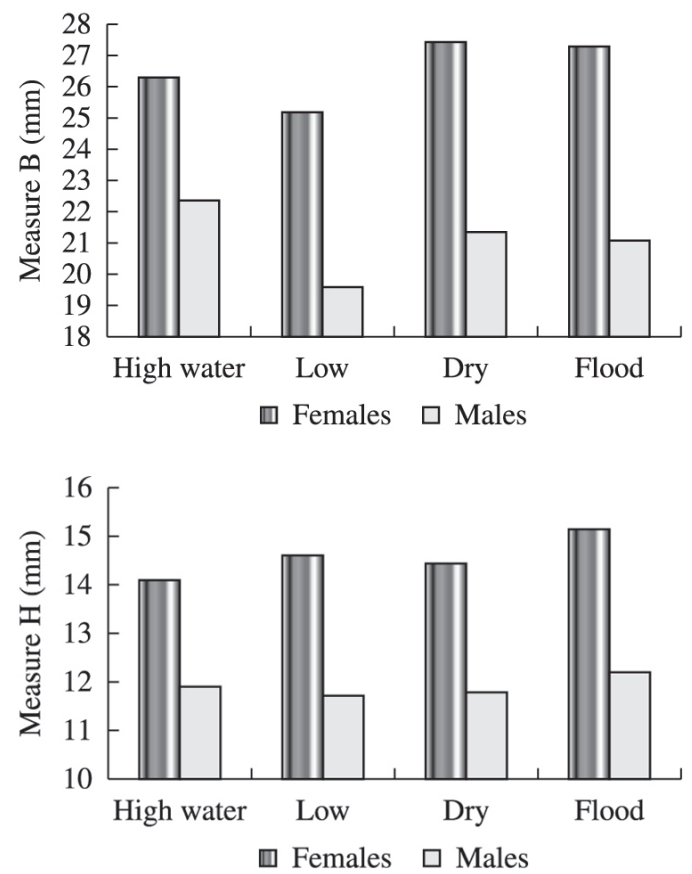

Figures 3. Variation of measurements A, B, I and $\mathrm{H}$ between the seasonal periods in individual male and female adults of C. aquaticum, in the Piuval bay, Pantanal of Poconé, MT. 

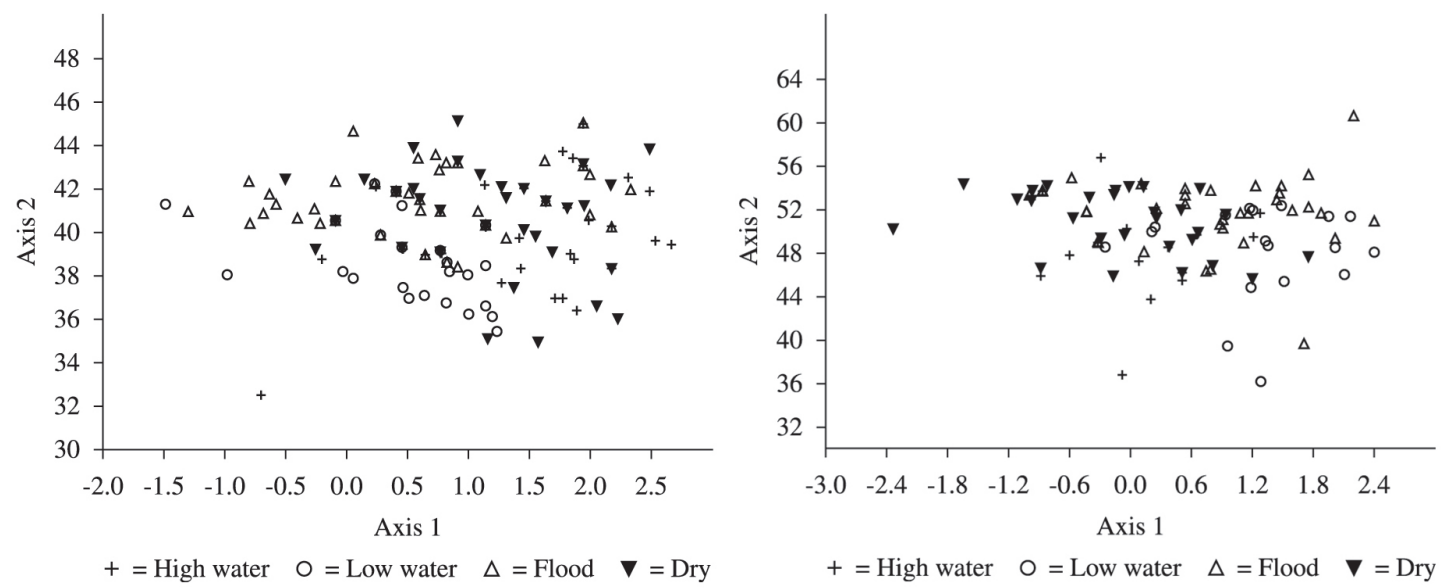

Figures 4. Canonic variables calculated in multivariate analysis (MANOVA) for individual adult C. aquaticum, male, 8; and female, 9; showing size variation between the seasonal periods in the Piuval bay, Pantanal of Poconé, MT.

C. aquaticum population shows sexual dimorphism in the last stages of development, different from other studies on Acrididae morphometry where this feature appears in other stages such as, for example, in Chromacris speciosa (Thunberg, 1824) (Romaleidae), where the difference between the sexes can be measured from the third stage (Turk and Barrera, 1976).

The measurements of immature individuals obtained from this study coincide with Zolessi (1956) descriptions in Uruguay in terms of body longitude (measurement B) and for the length of the hind femurs $(\mathrm{H})$ there are similarities up to the third stage. The populations raised in laboratory by Franceschini et al., (2005) in two locations in Argentina, Corrientes and Santa Fé, also possess similar measurements for those recorded in this study.

This population has sexual dimorphism in adults and the males are smaller than females with the differences occurring in the last development instars. The adults had significant variations between the seasonal periods in all the morphometric features assessed with the highest values recorded during the flood period, however, no standard size pattern was established for any of the periods. For adults, in terms of total body length and body size, the results obtained in this study are similar to the results presented by Adis et al., (2008) and according to these authors morphology varies with geography. In Latin America the individuals of $C$. aquaticum seems to be smaller in the tropic region and bigger in the limits north and south of the range distribution, but future studies can confirm this observation with more collection effort and more data.

\section{Conclusion}

The $C$. aquaticum population shows similar morphometric characteristics to other populations studied in South America. The patterns are similar for both nymphal and adults. Similarities can be found in the morphology of nymphs of this population, which came from the natural environment, to those developed in the laboratory in two areas of Argentina (Corrientes and Santa Fe) studied by Franceschini et al. (2005). The morphometric characters of the adults varied significantly and the definition of a standard size for the seasonal periods evaluated was not possible due to the higher values recorded during the flood period. This variation can be explained by the population phenology, which is characterised by the occurrence of generations per year (Silva et al., 2010). The population shows a sexual dimorphism for adults and it is observed that males are smaller than females in the last instars of development.

\section{Acknowledgements}

The authors dedicate this study to Prof. Dr. Joachim Adis (in memoriam) for the great knowledge, encouragement and dedication to the study of $C$. aquaticum and the constant support for research and studies carried out in the LETA of the Biosciences Institute of the Federal University of Mato Grosso (UFMT). We also thank Mr. João Louzano (Fazenda Ipiranga) for his help and for permitting the use of the location for this study, and to the laboratory technician Francisco Assis Gonçalves Rondon and the laboratory colleagues for their cooperation with the collections.

\section{References}

ADIS, J. and VICTORIA, RL., 2001. C 3 or C 4 macrophytes: a specific carbon source for the development of semi-aquatic and terrestrial arthropods in Central Amazonian river-floodplains to $\delta 13$ values. Isotopes in Environmental and Health Studies, vol. 37, no. 3, p. 193-198. http://dx.doi.org/10.1080/10256010108033295. PMid:11924850

ADIS, J. and JUNK, WJ., 2003. Feeding impact and bionomics of grasshopper Cornops aquaticum on the water hyacinth Eichhornia crassipes in the Central Amazonian foodplains. Studies on Neotropical Fauna and Environment, vol. 38, no. 3, p. 245-249. http://dx.doi.org/10.1076/snfe.38.3.245.28167. 
ADIS, J., LHANO, MG., HILL, M., JUNK, WJ., MARQUES, MI. and OBERHOLZER, H., 2004. What determines the number of juvenile instars in the tropical grasshopper Cornops aquaticum (Leptysminae: Acrididae: Orthoptera)? Studies on Neotropical Fauna and Environment, vol. 39, no. 2, p. 127-132. http://dx.doi. org/10.1080/01650520412331271729.

ADIS, J., BUSTORF, E., LHANO, MG., AMEDEGNATO, C. and NUNES, AL., 2007. Distribution of Cornops grasshoppers (Leptysminae: Acrididae: Orthoptera) in Latin America and the Caribbean Islands. Studies on Neotropical Fauna and Environment, vol. 42, no. 1, p. 11-24. http://dx.doi. org/10.1080/01650520600931719.

ADIS, J., SPERBER, CF., BREDE, E., CAPELlO, S., FRANCESCHINI, MC., HILL, M., LHANO, MG., MARQUES, MI., NUNES, A. and POLAR, LP., 2008. Morphometric differences in the grasshopper Cornops aquaticum (Bruner, 1906) from South America and South Africa. Journal of Orthoptera Research, vol. 17, no. 2, p. 141-147. http://dx.doi.org/10.1665/1082-6467-17.2.141.

AHNESJÖ, J. and FORSMAN, A., 2003. Correlated evolution of colour pattern and body size in polymorphic pygmy grasshoppers, Tetrix undulata. Journal of Evolutionary Biology, vol. 16, no. 6, p. 1308-1318. http://dx.doi.org/10.1046/j.1420-9101.2003.00610.x. PMid:14640422

BEGON, M., TOWNSEND, CR. and HARPER, JL., 2006. Ecology: from individuals to ecosystems. 4th. ed. Oxford: Blackwell Publishing. 759 p.

BREDE, E., ADIS, J. and SCHNEIDER, P., 2007. What is responsible for the variance in life history traits of South American semiaquatic grasshopper (Cornops aquaticum)? A test of three possible hypotheses. Studies on Neotropical Fauna and Environment, vol. 42, no. 3, p. 225-233. http://dx.doi.org/10.1080/01650520701414441.

CARBONELL, CS., 2002. The grasshopper tribe Phaeoparini (Acridoidea: Romaleidae). The Orthopterist's Society. 148 p. Publications on Orthopteran Diversity, no. 1.

CEPEDA-PIZARRO, J., VEGA, S., VÁSQUEZ, H. and ELGUETA, M., 2003. Morfometria y dimorfismo sexual de Elasmoderus wagenknechti (Liebermann) (Orthoptera: Tritiridae) en dos eventos de irrupción poblacional. Revista Chilena de Historia Natural, vol. 76, no. 3, p. 417-435. http://dx.doi.org/10.4067/ S0716-078X2003000300007.

CHERRIL, A., 2005. Body size and phenology of the grasshopper species Chorthippus brunneus with variable number of female instars (Orthoptera: Acrididae). Entomologia Generalis, vol. 28, no. 3, p. 219-231.

DIRSH, VM., 1953. Morphometrical studies on phases of desert locust. Anti-locust Bulletin, vol. 16, p. 1-34.

DOMENICO, FC., 2005. Nymphal development of Xyleus discoideus discoideus (Serville, 1931) (Acridoidea, Romaleidae, Romaleinae) in laboratory. Journal of Orthoptera Research, vol. 14, no. 2, p. 127-135. http://dx.doi.org/10.1665/1082-6467(2005)14[127:ND OXDD]2.0.CO;2.

FERREIRA, PSF., PIRES, EM., GUEDES, RNC., MENDES, M. and COELHO, L., 2006. Seasonal abundance and sexual variation in morphometric traits of Oxelytrum discicolle (Brulle, 1840) (Coleoptera: Silphidae) in Brazilian Atlantic Forest. Biota Neotropica, vol. 6, no. 2, p. 1-7. http://dx.doi.org/10.1590/S167606032006000200015 .

FERREIRA, AS. and VASCONCELLOS-NETO, J., 2001. Host plants of the grasshopper Cornops aquaticum (Bruner) (Orthoptera:
Acrididae) in the wetland of Poconé, MT, Brazil. Neotropical Entomology, vol. 30, no. 4, p. 523-533. http://dx.doi.org/10.1590/ S1519-566X2001000400003.

FILIN, I. and OVADIA, O., 2007. Individual size variation and population stability in a seasonal environment: a discrete-time model and its calibration using grasshoppers. The American Naturalist, vol. 170, no. 5, p. 719-733. http://dx.doi.org/10.1086/522091. PMid:17926294

FORTNEY, RH., BENEDICT, M., GOTTGENS, JF., WALTERS, TL., LEADY, BS. and RENTCH, J., 2004. Aquatic plant community composition and distribution along an inundation gradient at two ecologically-distinct sites in the Pantanal region of Brazil. Wetlands Ecology and Management, vol. 12, no. 6, p. 575-585. http://dx.doi.org/10.1007/s11273-005-1763-0.

FRANCESCHINI, MC., CAPELLO, S., LHANO, MG., ADIS, J. and WYSIECKI, ML., 2005. Morfometria de los estádios ninfales de Cornops aquaticum Bruner (1906) (Acrididae Leptysminae) en Argentina. Amazoniana, vol. XVIII, no. 3-4, p. 373-386.

GUIDO, AS. and PERKINS, BD., 1975. Biology and host specifity Cornops aquaticum (Bruner) (Orthoptera: Acrididae), a potential biological control agent for waterhyacinth. Environmental Entomology, vol. 4, no. 3, p. 400-404.

HAMMER, O. and HARPER, DAT., 2008. Past version 1.81. Oslo: University of Oslo. Available from: <http://folk.uio.no/ ohammer/past2008>. Access in: 10 Sept. 2008.

InfoStat, 2002. Infostat: version 1.1. Manual del usuário. Argentina: Grupo Infostat/FCA/Universidad Nacional de Córdoba.

JUNK, WJ., CUNHA, CN., WANTZEN, KM., PETERMANN, P., STRUSSMANN, C., MARQUES, MI. and ADIS, J., 2006. Biodiversity and its conservation in the Pantanal of Mato Grosso, Brazil. Aquatic Sciences, vol. 68, no. 3, p. 278-309. http://dx.doi. org/10.1007/s00027-006-0851-4.

KLINGENBERG, CP. and SPENCE, JR., 1997. On the role of body size for life-history evolution. Ecological Entomology, vol. 22, no. 1, p. 55-68. http://dx.doi.org/10.1046/j.1365-2311.1997.00031.x.

LHANO, MG., 2002. Aspectos biológicos e ecológicos de Cornops aquaticum (Bruner, 1906) (Orthoptera: Acrididae) em Eichhornia azurea (Swartz) Kunth (Pontederiaceae) no Pantanal de Poconé, Mato Grosso. Mato Grosso: Universidade Federal de Mato Grosso. 123 p. Dissertação de Mestrado.

LHANO, MG., ADIS, J., MARQUES, MI. and BATTIROLA, LD., 2005. Cornops aquaticum (Orthoptera, Acrididae, Leptysminae): aceitação de plantas alimentares por ninfas vivendo em Eichhornia azurea (Pontederiaceae) no Pantanal Norte, Brasil. Amazoniana, vol. XVIII, no. 3-4, p. 397-404.

OBERHOLZER, IG. and HILL, MP., 2001. How safe is the grasshopper Cornops aquaticum for release on water hyacinth in South Africa? In JULIEN, MH., HILL, MP., CENTER, TD. and JIANQING, D. (Eds.). Biological and integrated control of water hyacinth, Eichhornia crassipes. Australia: ACIAR. p. 82-88. ACIAR Proceedings, no. 102.

PIRES, EM. and GUEDES, RNC., SERRÃO, JEP. and FERREIRA, SF., 2008. Seasonal and interpopulational morphometry variation of Platyscytus decempunctatus (Carvalho, 1945) (Heteroptera: Miridae). Biota Neotropica, vol. 8, no. 2, p. 21-28.

ROONWAL, ML., 1981. Field bioecology and morphometry of some central indian grasshoppers (Acridoidea), with notes on a swimming species (Tetrigoidea). Proceedings of the Zoological Society, vol. 32, p. 97-106. 
SEFFRIN, RCAS., COSTA, EC., COUTO, MRM. and LOPES, SJ., 2006. Medidas morfométricas de fêmeas e machos de Oncideres dejeani Thompson, 1868 (Coleoptera: Cerambycidae). Ciência Rural, vol. 36, no. 4, p. 1313-1316. http://dx.doi.org/10.1590/ S0103-84782006000400044.

SILVA, FRJ., MARQUES, MI., BATTIROLA, LD. and LHANO, MG., 2010. [Phenology of Cornops aquaticum (Bruner) (Orthoptera: Acrididae) in Eichhornia azurea (Pontederiaceae) in the northern region of Pantanal of Mato Grosso, Brazil]. Neotropical Entomology, vol. 39, no. 4, p. 535-542. http://dx.doi.org/10.1590/S1519566X2010000400011. PMid:20877988
TURK, SZ. and BARRERA, M., 1976. Acridios del NOA. I. Estudios biologicos, morfométricos y aspectos ecológicos de Chromacris speciosa (Thunberg) (Acrididae, Romaleinae). Acta Zoológica Lilloana, vol. 32, p. 121-145.

WEST-EBERHARD, MJ., 1989. Phenotypic plasticity and the origins of diversity. Annual Review of Ecology and Systematics, vol. 20 , no. 1 , p. $249-278$. http://dx.doi.org/10.1146/annurev. es.20.110189.001341.

ZOLESSI, LC., 1956. Observaciones sobre Cornops aquaticum Br. (Acridoidea, Cyrtacanthacr.) en el Uruguay. Revista de la Sociedad Uruguaya de Entomologia, vol. 1, p. 3-28. 


\section{Erratum}

Due to a error in the article "Morphometry of Cornops aquaticum (Orthoptera: Acrididae: Leptysminae) in the Pantanal of Mato Grosso, Brazil" published in volume 74, issue 3, p. 730-738, in the authors affiliations, where you read "Centro de Ciências Agrárias, Ambientais e Biológicas - CCAAB, Universidade Federal do Recôncavo da Bahia - UFRB, Av. Alberto Passos, 294, Centro, CEP 44380-000, Cruz das Almas, BA, Brazil", should read "Centro de Ciências Agrárias, Ambientais e Biológicas - CCAAB, Universidade Federal do Recôncavo da Bahia - UFRB, Rua Rui Barbosa, 710, Centro, CEP 44380-000, Cruz das Almas, BA, Brazil”. 